\title{
Peran Orang Tua dalam Menyediakan Home Literacy Environment (HLE) pada Anak Usia Dini
}

\author{
Novia Sari Hermawati ${ }^{\circledR}{ }^{\bowtie}$, Sugito $^{2}$ \\ Pendidikan Anak Usia Dini, Universitas Negeri Yogyakarta, Indonesia(1) \\ Pendidikan Luar Sekolah, Universitas Negeri Yogyakarta, Indonesia(2) \\ DOI: $\underline{10.31004 / \text { obsesi.v6i3.1706 }}$
}

\begin{abstract}
Abstrak
Perkembangan literasi merupakan salah satu substansi penting bagi perkembangan bahasa anak karena perkembangan bahasa merupakan kemampuan untuk menggunakan semua keterampilan berbahasa manusia yang mencakup kemampuan berbicara, menulis, membaca, dan menyimak sebagai bentuk ekspresi dan memaknai. Penelitian ini bertujuan untuk mengetahui peran orang tua dalam menyediakan Home Literacy Environment (HLE) pada anak usia dini. Penelitian ini merupakan penelitian dengan pendekatan kualitatif deskriptif. Subjek penelitian adalah 10 orang tua yang memiliki anak usia 3-6 tahun dengan tingkat pendidikan dan sosial ekonomi berbeda di Klaten. Teknik pengumpulan data meliputi observasi, wawancara, dan dokumentasi. Analisis data yang digunakan adalah pengumpulan data, reduksi data, penyajian data, dan penarikan kesimpulan. Peran orang tua dalam menyediakan HLE pada anak usia dini adalah sebagai sumber literasi (guru atau pendamping literasi bagi anak), fasilitator literasi (menyediakan ruang baca, buku atau bahan bacaan, dan APE literasi untuk anak), dan sebagai pengatur terlaksananya program literasi. Sedangkan, peran anak adalah sebagai sasaran utama orang tua dalam menerapkan HLE.
\end{abstract}

Kata Kunci: orang tua; lingkungan literasi rumah; anak usia dini.

\begin{abstract}
Literacy development is one of the important substances for children's language because language development is the ability to use all human language skills that develop speaking, writing, reading, and listening skills as a form of expression and meaning. This study aims to determine the role of parents in providing a Home Literacy Environment (HLE) in early childhood. This research is a descriptive qualitative approach. The research subjects were 10 parents of children aged 3-6 years with different educational and socioeconomic levels in Klaten. Data collection techniques include observation, interviews, and documentation. Data analysis used is data collection, data reduction, data presentation, and drawing conclusions. The role of parents in providing HLE to early childhood is as a source of literacy (teachers or literacy assistants for children), literacy facilitators (providing reading rooms, books or reading materials, and literacy APE for children), and as a regulator of the implementation of literacy programs. While the role of children is as the main target of parents in implementing HLE.
\end{abstract}

Keywords: parents; home literacy environment; early childhood.

Copyright (c) 2021 Novia Sari Hermawati, Sugito

$\square$ Corresponding author :

Email Address : noviasari.2020@student.uny.ac.id (Klaten, Jawa Tengah)

Received 1 May 2021, Accepted 2 September 2021, Published 17 September 2021 


\section{PENDAHULUAN}

Perkembangan literasi atau keaksaraan awal merupakan salah satu substansi penting bagi perkembangan bahasa anak. Perkembangan bahasa merupakan kemampuan untuk menggunakan semua keterampilan berbahasa manusia untuk berekspresi dan memakna (Madyawati, 2016). Lebih lanjut dikemukakan bahwa perkembangan bahasa pada anak mencakup empat komponen, yaitu: kemampuan berbicara, kemampuan menulis, kemampuan membaca, dan kemampuan menyimak. Hasil studi The World's Most Literate Nations (WMLN) 2016 menunjukkan bahwa peringkat membaca orang Indonesia berada di urutan ke-60 dari 61 negara yang diteliti (Miller \& McKenna, 2016). Hasil kajian Perpustakaan Nasional RI Tahun 2016-2019 juga menunjukkan bahwa indeks kegemaran membaca Indonesia masih rendah (Perpustakaan Nasional, 2020). Hal tersebut menunjukkan bahwa perlu adanya penanaman budaya literasi yang dimulai sejak anak masih usia dini agar kemampuan literasi anak Indonesia dapat berkembang menjadi lebih baik.

Lingkungan keaksaraan di rumah merupakan prediktor penting bagi pengembangan bahasa dan literasi anak-anak (Puglisi et al., 2017). Sejak lahir, anak-anak meletakkan dasar untuk literasi saat mereka mengeksplorasi dan menganalisis suara, simbol, dan cetakan di sekitar mereka (Weigel et al., 2017). Selama masa bayi, balita, dan tahun-tahun prasekolah anak-anak memperoleh dasar literasi dan bahasa yang akan membantu mereka berhasil setelah mereka memulai sekolah formal. Studi etnografi dan sosio-linguistik selama setengah abad terakhir telah menunjukkan bahwa di seluruh kelompok budaya, bahasa dan sosial, keluarga dapat menjadi tempat yang kaya bagi pengembangan literasi anak-anak (Anderson et al., 2017). Melalui pengalaman sehari-hari, anak-anak kecil menemukan kesempatan untuk mengembangkan kemampuan bahasa lisan, melatih keterampilan literasi yang muncul, memperoleh pengetahuan tentang bentuk dan fungsi bahasa tertulis, dan menyempurnakan kemampuan kognitif mereka.

Keterampilan berbahasa telah terbukti dipengaruhi oleh peluang yang diberikan orang tua untuk pengalaman bahasa dan literasi melalui interaksi khusus seperti membaca buku bersama (Rose et al., 2018). Orang tua sebagai pendidik di rumah sudah semestinya mampu menyediakan lingkungan rumah yang dapat mendukung perkembangan literasi anak agar dapat meningkatkan perkembangan kemampuan bahasa anak. Para orang tua didorong untuk membacakan buku kepada anak-anak mereka sejak usia dini sebagai langkah awal untuk mempersiapkan mereka dalam memperoleh keaksaraan setelah masuk sekolah. Menurut model keaksaraan rumah (Silinskas et al., 2020; Zhang et al., 2020), ada dua jenis pengalaman keaksaraan yang terjadi di rumah: pengalaman keaksaraan informal dan formal. Pengalaman literasi informal berfokus pada makna dan mengekspos anak-anak untuk mencetak secara kebetulan melalui kegiatan seperti membaca buku bersama. Pada gilirannya, pengalaman keaksaraan formal berfokus pada kode dan mengekspos anak-anak untuk mencetak secara langsung melalui kegiatan seperti pengajaran huruf dan kata. Pengalamanpengalaman langsung yang didapatkan oleh anak ini selanjutnya akan berdampak pada peningkatkan keterampilan literasi yang mereka miliki.

Lingkungan literasi rumah (HLE) telah didefinisikan baik sebagai frekuensi membaca bersama orang tua-anak prasekolah atau sebagai definisi luas multifaset untuk memasukkan ukuran durasi membaca buku bergambar bersama, jumlah buku bergambar, perhatian bersama, dan variabel kontekstual sebagai literasi keluarga (Buvaneswari \& Padakannaya, 2017; Mascarenhas et al., 2017). HLE merupakan praktik kegiatan di rumah yang dilakukan oleh orang tua dalam kaitannya dengan kegiatan yang berhubungan dengan keterampilan membaca, menulis, dan berbahasa lisan. Praktik keaksaraan di rumah merujuk pada jenis kegiatan berorientasi keaksaraan yang terjadi di rumah dan mencakup praktik yang berhubungan dengan membaca (misalnya, membaca buku bersama anak, pengajaran orang tua tentang nama huruf) dan praktik yang berhubungan dengan menulis (misalnya, kegiatan menulis bersama anak, pengajaran orang tua tentang menulis nama atau kata lain) (Guo et al., 1368 | Jurnal Obsesi : Jurnal Pendidikan Anak Usia Dini, 6(3), 2022 
2021). Van Steensel (Buvaneswari \& Padakannaya, 2017) menjelaskan tiga jenis lingkungan literasi rumah: (a) lingkungan literasi rumah yang kaya, dimana orang tua dan anak-anak berpartisipasi dalam berbagai kegiatan literasi; (b) lingkungan literasi rumah yang diarahkan anak, dimana aktivitas literasi kurang, tetapi aktivitas penting seperti membaca bersama, kunjungan perpustakaan, dan lain-lain; dan (c) lingkungan literasi rumah yang buruk, dimana sangat sedikit partisipasi orang tua atau anak dalam kegiatan literasi.

Terciptanya HLE yang terarah dan terencana dapat mendukung perkembangan dan kinerja anak dalam berbagai tahapan pendidikan. Kualitas dan kuantitas kegiatan terkait keaksaraan yang melibatkan orang tua dengan anak-anak mereka harus berpengaruh bagi perkembangan keaksaraan anak-anak mereka mengingat anak-anak menghabiskan lebih banyak waktu di rumah daripada di sekolah. Cara keluarga terlibat dan mengikutsertakan anak-anak dalam praktik keluarga sehari-hari mempengaruhi perkembangan literasi dan numerasi, serta perkembangan perilaku dan kognitif anak-anak mereka (Niklas et al., 2016). Lebih lanjut dikemukakan bahwa frekuensi orang tua dalam membaca untuk anak, membaca di rumah, kunjungan perpustakaan, dan beberapa buku di rumah memprediksi kemampuan membaca anak di kemudian hari. Selain itu, kebiasaan literasi orang tua dapat memprediksi kualitas kompetensi literasi anak. Orang tua atau pengasuh yang menunjukkan kegembiraan membaca memiliki pengaruh terbesar pada seorang anak, yaitu kemampuan membaca dan minat membaca seumur hidup (Buvaneswari \& Padakannaya, 2017).

HLE sangat penting untuk dapat diimplementasikan dalam pembelajaran di rumah karena dapat menjadi salah satu program yang dapat digunakan orang tua dalam mengembangkan perkembangan bahasa anak khususnya perkembangan keaksaraan awal sekaligus dalam rangka mempersiapkan anak untuk memasuki jenjang pendidikan sekolah dasar. Kebijakan pendidikan yang menekankan peran orang tua sebagai pendidik pertama bagi anak dapat menjadi cara yang efektif untuk meningkatkan efektivitas orang tua dalam mendukung pertumbuhan, perkembangan, dan kesejahteraan anak khususnya. Pengaturan lingkungan literasi di rumah yang baik akan menentukan hasil pencapaian perkembangan keterampilan literasi anak yang baik pula di masa mendatang. Meskipun telah terdapat penelitian-penelitian terdahulu yang membahas mengenai Home Literacy Environment (HLE), namun penelitian mengenai peran orang tua dalam menyediakan HLE pada anak usia dini masih belum banyak dilakukan. Hal inilah yang melandasi mengapa penelitian ini perlu dilakukan, yaitu untuk mengetahui peran orang tua dalam menyediakan HLE pada anak usia dini dilihat dari latar belakang tingkat pendidikan dan sosial ekonomi orang tua yang berbeda-beda. Selanjutnya, diharapkan agar dapat memberikan hasil dan manfaat mengenai HLE bagi perkembangan anak khususnya dalam kaitannya dengan keterampilan membaca, menulis, dan berbahasa lisan di tahun-tahun awal sekolah.

\section{METODOLOGI}

Penelitian ini merupakan penelitian dengan pendekatan kualitatif deskriptif. Penelitian deskriptif dimaksudkan untuk menguraikan secara struktural terkait dengan realita yang terjadi pada populasi tertentu serta untuk memberikan jawaban atas permasalahan dan/atau mendapatkan informasi mendalam mengenai suatu fenomena engan menggunakan metode penelitian pendekatan kuantitatif (Yusuf, 2017). Melalui pendekatan kualitatif deskriptif maka dapat memberikan gambaran berdasarkan fakta terkait peran orang tua dalam menyediakan HLE pada anak usia dini secara lebih mendalam serta melakukan analisis terhadap data yang didapatkan. Penelitian ini dilaksanakan di wilayah Kabupaten Klaten dan dilakukan mulai pada tanggal 1 Mei 2021 sampai dengan tanggal 31 Mei 2021. Pemilihan tempat penelitian di wilayah Kabupaten Klaten karena berdekatan langsung dengan rumah peneliti sehingga memudahkan peneliti untuk menggali informasi secara menyeluruh. Subjek penelitian dalam penelitian kualitatif disebut sebagai informan dimana yang menjadi informan dalam penelitian ini yaitu orang tua. Subjek penelitian ini diambil 
dengan teknik purposive sampling. Identifikasi lokasi atau individu dipilih secara sengaja untuk studi yang diusulkan (Flick, 2014). Subjek penelitian ini adalah 10 orang tua yang memiliki anak usia 3-6 tahun dengan tingkat pendidikan dan sosial ekonomi yang berbeda. Tingkat pendidikan dan sosial ekonomi yang berbeda dipilih dengan maksud agar dapat memberikan hasil penelitian yang lebih bervariasi. Kemudian, untuk menjaga kerahasiaan data informan maka peneliti menggunakan nama inisial. Data informan selengkapnya dapat dilihat pada tabel 1.

Tabel 1. Data Informan (Orang Tua)

\begin{tabular}{cccc}
\hline No & Inisial Ibu/Ayah & Pendidikan Terakhir & Pekerjaan \\
\hline 1 & WN/FR & SMA/SMA & Karyawan Swasta/Karyawan Swasta \\
2 & RZ/CH & S1/S1 & Guru/Karyawan Swasta \\
3 & HY/IM & D3/S1 & Bidan/Guru \\
4 & NC/AH & SMA/SMA & Ibu Rumah Tangga/Karyawan Swasta \\
5 & AN/FT & SMA/S1 & Ibu Rumah Tangga/Karyawan Swasta \\
6 & NS/IW & SMA/SMA & Wirausaha/ Karyawan Swasta \\
7 & VV/TF & S1/S1 & Guru/Guru \\
8 & TK/RN & D3/D3 & Perawat/Karyawan Swasta \\
9 & IN/IL & S1/S2 & Guru/Dosen \\
10 & WL/AF & S1/D3 & Guru/Karyawan Swasta \\
\hline
\end{tabular}

Teknik pengumpulan data dalam penelitian ini meliputi observasi, wawancara, dan dokumentasi. Penelitian ini menggunakan observasi dan wawancara terbuka karena peneliti menanyakan pertanyaan-pertanyaan umum dan tidak terstruktur sehingga dapat memungkinkan partisipan untuk memberikan pandangannya secara bebas. Sebelum melakukan observasi dan wawancara, peneliti terlebih dahulu mengatur jadwal dan waktu kunjungan dengan orang tua. Setelah itu, peneliti menyusun instrumen penelitian yang akan digunakan dalam proses wawancara dengan orang tua.

Tabel 2. Kisi-kisi Instrumen Penelitian

\begin{tabular}{|c|c|c|c|}
\hline No & Aspek & Teknik & Informan \\
\hline 1 & $\begin{array}{l}\text { Pemahaman orang tua tentang Home Literacy } \\
\text { Environment (HLE) }\end{array}$ & $\begin{array}{c}\text { Wawancara dan } \\
\text { dokumentasi }\end{array}$ & Orang tua \\
\hline 2 & $\begin{array}{l}\text { Langkah awal yang disiapkan orang tua dalam } \\
\text { menyediakan Home Literacy Environment (HLE) }\end{array}$ & $\begin{array}{l}\text { Wawancara, observasi, dan } \\
\text { dokumentasi }\end{array}$ & Orang tua \\
\hline 3 & $\begin{array}{l}\text { Bentuk kegiatan Home Literacy Environment } \\
\text { (HLE) yang diberikan orang tua }\end{array}$ & $\begin{array}{c}\text { Wawancara, observasi, dan } \\
\text { dokumentasi }\end{array}$ & Orang tua \\
\hline 4 & $\begin{array}{l}\text { Faktor pendukung orang tua dalam } \\
\text { menyediakan Home Literacy Environment (HLE) }\end{array}$ & Wawancara dan observasi & Orang tua \\
\hline 5 & $\begin{array}{l}\text { Kendala yang dihadapi orang tua dalam } \\
\text { menyediakan Home Literacy Environment (HLE) }\end{array}$ & Wawancara dan observasi & Orang tua \\
\hline
\end{tabular}

Instrumen penelitian (tabel 2) disusun dengan mengadaptasi dari penelitian yang dilakukan oleh Kumalasari \& Sugito (2020) yang kemudian dikembangkan dan dimodifikasi sesuai dengan teori yang ada. Kisi-kisi instrumen meliputi aspek yang diteliti, teknik pengumpalan data, dan informan. Instrumen penelitian ini dimaksudkan agar hasil wawancara sesuai dengan alur dan cara yang ditetapkan. Wawancara dilakukan secara langsung dengan orang tua untuk mengetahui: (1) pemahaman orang tua tentang Home Literacy Environment (HLE), (2) langkah awal yang disiapkan orang tua dalam menyediakan Home Literacy Environment (HLE), (3) bentuk kegiatan Home Literacy Environment (HLE) yang diberikan oleh orang tua, (4) faktor pendukung orang tua dalam menyediakan Home Literacy Environment (HLE), (5) kendala yang dihadapi orang tua dalam menyediakan Home Literacy 
Environment (HLE). Dokumentasi dilakukan dengan mengumpulkan data sekunder berupa foto yang berkaitan dengan permasalahan yang diteliti. Bagan model penelitian dapat dilihat pada gambar 1.

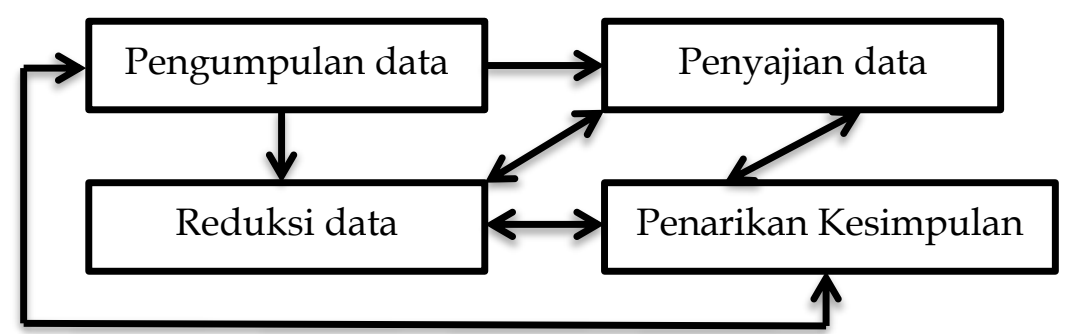

Gambar 1. Bagan Model Analisis Miles dan Huberman.

Proses analisis data dilakukan secara kualitatif interaktif menggunakan model analisis dari Miles dan Huberman. Model analisis Miles dan Huberman terdiri dari empat tahapan, yaitu pengumpulan data, reduksi data, penyajian data, dan penarikan kesimpulan (Miles et al., 2014; Miles \& Huberman, 1994). Tahap pertama adalah pengumpulan data. Pada tahap ini peneliti membuat kisi-kisi instrumen, menganalisis sumber referensi, dan melakukan wawancara terhadap informan (orang tua). Tahap kedua adalah reduksi data. Pada tahap ini peneliti memilih dan menyederhanakan hasil wawancara sesuai dengan tujuan penelitian. Tahap ketiga adalah penyajiaan data. Pada tahap ini data yang sudah didapatkan disajikan dalam bentuk narasi dan dianalisis berdasarkan pemahaman yang diperoleh dari representasi. Tahap keempat adalah penarikan kesimpulan. Pada tahap ini peneliti menarik kesimpulan mengenai peran orang tua dalam menyediakan HLE pada anak usia dini.

\section{HASIL DAN PEMBAHASAN}

\section{Pemahaman orang tua tentang Home Literacy Environment (HLE)}

Pemahaman setiap orang tua tentang Home Literacy Environment (HLE) berbeda-beda tergantung pada sudut pandang, tingkat pengetahuan, dan tingkat pendidikan yang dimiliki. Berdasarkan hasil wawancara yang telah dilakukan, orang tua yang memiliki tingkat pengetahuan dan tingkat pendidikan yang tinggi cenderung lebih memahami arti dari lingkungan literasi di rumah. Perbedaan pemahaman tersebut dapat dilihat dari tabel 3 hasil wawancara yang telah peneliti lakukan dengan orang tua. Sedangkan gambaran pelaksanaan wawancara terhadap responden dapat dilihat pada gamba 2 dan 3.

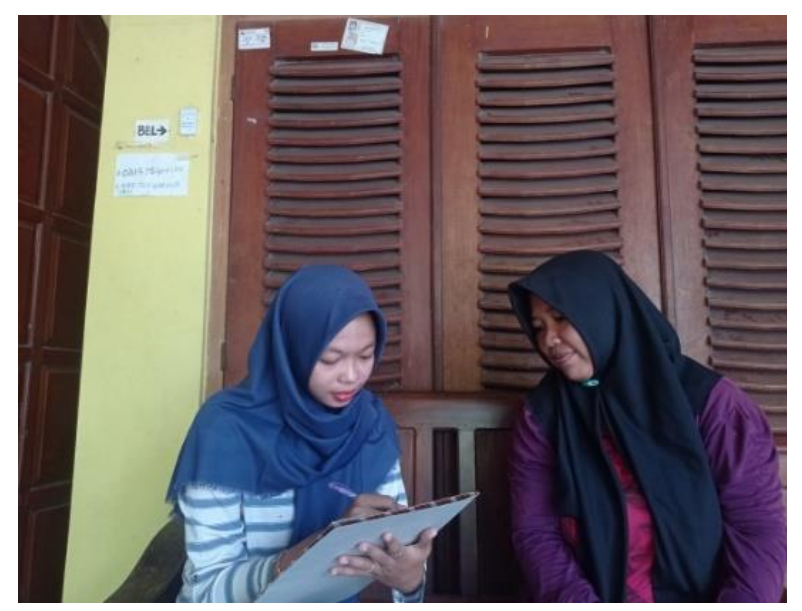

Gambar 2. Wawancara dengan Ibu IN.

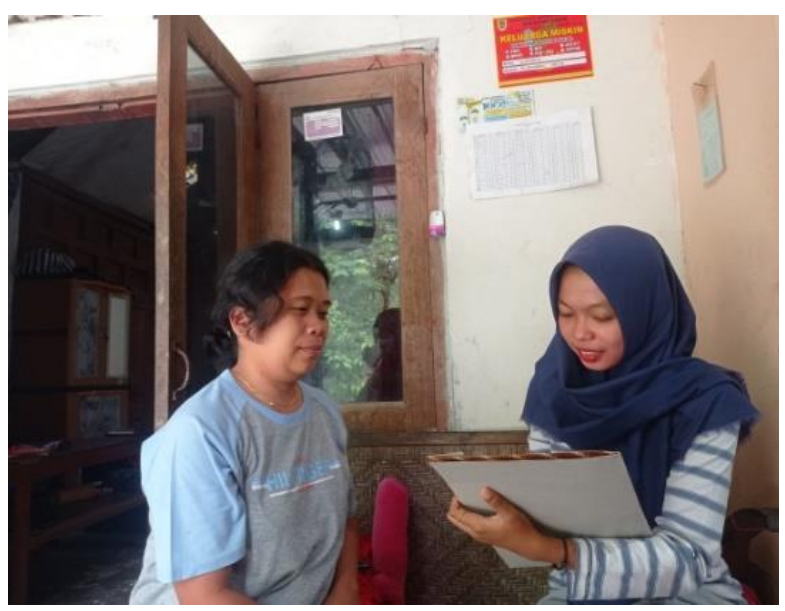

Gambar 3. Wawancara dengan Ibu HY. 
Berdasarkan hasil dari wawancara tersebut maka dapat disimpulkan bahwa lingkungan literasi di rumah atau Home Literacy Environment (HLE) merupakan lingkungan yang dapat mendukung orang tua dalam memberikan stimulasi untuk perkembangan bahasa anak ketika berada di rumah. Kegiatan literasi di rumah biasanya dilakukan melalui aktivitas membaca buku bersama, mengenalkan anak dengan berbagai macam buku bacaan, maupun mengajarkan anak membaca dan menulis awal.

Tabel 3. Hasil Wawancara Aspek No. 1

\begin{tabular}{ccc}
\hline Pertanyaan & Inisial & Jawaban \\
\hline Menurut Ibu, apa arti & RZ & Lingkungan literasi di rumah merupakan aktivitas di rumah yang
\end{tabular}

dari lingkungan dilakukan atau diterapkan oleh orang tua kepada anak untuk

literasi di rumah? mengajarkan dan meningkatkan kemampuan berbahasa anak dalam membaca dan menulis sejak usia dini.

WN Menurut saya, lingkungan literasi di rumah sangat penting sekali melihat begitu banyaknya manfaat yang didapat dari berliterasi sendiri. Lingkungan literasi bisa membawa dampak perubahan yang lebih baik di zaman yang serba digital seperti sekarang ini. Dengan menghidupkan lingkungan literasi kita bisa menambah wawasan yang lebih luas, mengasah kreativitas, dan bisa menambah keeratan dan kehangatan hubungan antara orang tua dengan anak, satu individu dengan individu yang lainnya, dan satu keluarga dengan keluarga yang lainnya. Dengan melihat data yang ada, begitu masih minimnya lingkungan literasi di negara ini, maka alangkah baiknya dimulai dari diri sendiri dari keluarga sendiri, kita menciptakan lingkungan literasi tersebut agar manfaat-manfaat yang sangat banyak bisa dirasakan secara nyata.

HY Pembiasaan pola hidup membaca buku.

NC Kemampuan dalam berkomunikasi dan berbahasa untuk masa awal belajar berbicara.

AN Lingkungan yang mendukung kegiatan pembiasaan membaca pada anak.

NS Lingkungan literasi merupakan lingkungan yang menerapkan kegiatan membaca pada anak.

VV Lingkungan yang menyediakan berbagai macam buku yg bisa menarik minat baca anak.

TK Lingkungan yang menyediakan atau mendukung kemampuan berbahasa awal anak.

IN Lingkungan di sekitar rumah yang digunakan untuk mendukung pembelajaran literasi anak usia dini. Lingkungan tersebut dapat berupa perilaku, sikap ataupun interaksi antara orang tua dan anak dalam mengembangkan pembelajaran literasi sejak dini di rumah.

WL Lingkungkan literasi di rumah merupakan suatu kegiatan yang dilakukan oleh orang tua dalam rangka mengembangkan kemampuan berbahasa dan keaksaraan anak usia dini yang meliputi kegiatan membaca dan menulis.

\section{Langkah awal yang dilakukan oleh orang tua dalam menyediakan Home Literacy Environment (HLE)}

Berdasarkan hasil wawancara dan observasi yang telah dilakukan, dapat disimpulkan bahwa lingkungan literasi di rumah dapat terbentuk karena adanya kesadaran orang tua tentang pentingnya berliterasi dan dukungan dari peran aktif dan kerjasama yang baik antara orang tua dengan anaknya. Orang tua merupakan sumber belajar pertama bagi anak-anaknya 1372 | Jurnal Obsesi : Jurnal Pendidikan Anak Usia Dini, 6(3), 2022 
sehingga apa yang didapatkan oleh anak sangat dipengaruhi oleh peran orang tua dalam mendidik anaknya. Dukungan yang diberikan oleh orang tua dapat berupa ketersediaan waktu maupun penyediaan fasilitas yang dapat mendukung kegiatan berliterasi di rumah seperti dengan menyediakan ruang baca, buku atau bahan bacaan, dan APE literasi. Hasil wawancara dan observasi dapat dilihat dari tabel 4 dan dokumentasi pada gambar 4 dan 5 .

Tabel 4. Hasil Wawancara Aspek No. 2

\begin{tabular}{|c|c|c|}
\hline Pertanyaan & Inisial & Jawaban \\
\hline \multirow{16}{*}{$\begin{array}{l}\text { Langkah awal } \\
\text { apa yang perlu } \\
\text { Ibu siapkan } \\
\text { dalam } \\
\text { menyediakan } \\
\text { lingkungan } \\
\text { literasi di } \\
\text { rumah? }\end{array}$} & RZ & Langkah awal yang perlu disiapkan yaitu orang tua perlu memiliki \\
\hline & & kesadaran tentang pentingnya pendidikan literasi sejak dini, seperti dengan \\
\hline & & menjadikan kegiatan literasi sebagai kebiasaan sehari-hari dan menyediakan \\
\hline & & bahan maupun alat yang dapat mendukung kegiatan literasi anak di rumah. \\
\hline & WN & Langkah awal yang perlu disiapkan yaitu dimulai dari diri sendiri, dengan \\
\hline & & menanamkan rasa cinta pada literasi, karena jika kita sudah cinta dengan \\
\hline & & literasi maka kita akan dengan mudah memberi pemahaman serta mengajak \\
\hline & & $\begin{array}{l}\text { anak untuk cinta literasi dengan begitu lingkungan literasi di rumah bisa } \\
\text { tercipta. }\end{array}$ \\
\hline & HY & $\begin{array}{l}\text { Menyediakan sarana dan prasarana dalam pembentukan lingkungan literasi } \\
\text { di rumah. }\end{array}$ \\
\hline & $\mathrm{NC}$ & $\begin{array}{l}\text { Menyediakan peralatan yang mendukung untuk program literasi di rumah } \\
\text { seperti buku cerita, dan lain-lain. }\end{array}$ \\
\hline & AN & Buku, flash card, puzzle, dan lain-lain. \\
\hline & NS & $\begin{array}{l}\text { Langkah awal yang perlu disiapkan yaitu tempat dan media membaca atau } \\
\text { buku yang memadai. }\end{array}$ \\
\hline & VV & $\begin{array}{l}\text { Membuat ruangan belajar untuk baca bersama anak agar anak mampu } \\
\text { menikmati suasana belajar. }\end{array}$ \\
\hline & TK & $\begin{array}{l}\text { Menyediakan berbagai macam objek yang mendukung seperti buku cerita, } \\
\text { alat tulis, flash card, dan lain-lain. }\end{array}$ \\
\hline & IN & $\begin{array}{l}\text { Memahami pentingnya literasi untuk anak usia dini dan membentuk } \\
\text { kegiatan untuk mendukung literasi anak. }\end{array}$ \\
\hline & WL & $\begin{array}{l}\text { Langkah awal yang harus dipersiapkan orang tua dalam menyediakan } \\
\text { lingkungan literasi di rumah yaitu: pertama, orang tua harus menyadari } \\
\text { akan arti pentingnya literasi untuk perkembangan anak usia dini. Hal ini } \\
\text { bisa dilakukan dengan menerapkan kegiatan literasi dalam kehidupan } \\
\text { sehari-hari pada saat orang tua berinteraksi dengan anak, maka sebisa } \\
\text { mungkin orang tua memberikan stimulasi yang tepat untuk } \\
\text { mengembangkan kemampuan literasi anak. Kedua, menyediakan alat } \\
\text { pendukung pengembangan literasi anak di rumah seperti menyediakan } \\
\text { media pembelajaran dan buku-buku bacaan. }\end{array}$ \\
\hline
\end{tabular}

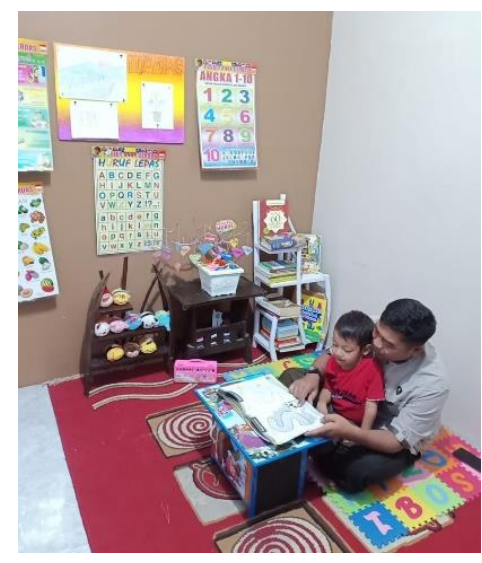

Gambar 4. Hasil observasi di rumah Ibu TF (Ayah TF sedang memperkenalkan gambar huruf "S" pada anaknya).

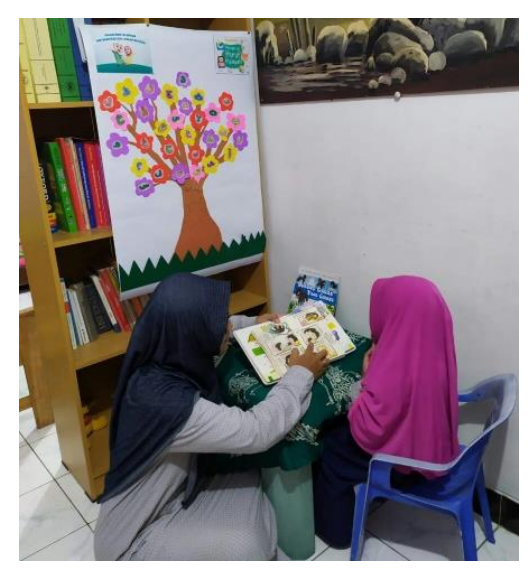

Gambar 5. Hasil observasi di rumah Ibu TK (Ibu TK sedang membacakan cerita bergambar pada anaknya). 


\section{Bentuk kegiatan Home Literacy Environment (HLE) yang diberikan oleh orang tua}

Berdasarkan hasil wawancara yang telah dilakukan, dapat disimpulkan bahwa bentuk kegiatan Home Literacy Environment (HLE) yang diberikan orang tua yaitu orang tua menjadikan kegiatan literasi di rumah sebagai suatu pembiasaan dalam keluarga (seperti membacakan buku, cerita, dan dongeng) dan menyediakan fasilitas literasi seperti ruang baca, buku atau bahan bacaan, dan APE literasi untuk anak. Selain itu, hasil observasi juga menunjukkan bahwa melalui kegiatan-kegiatan HLE yang orang tua berikan kepada anak membantu orang tua dalam mengajarkan anak-anak mereka mengenai berbagai kemampuan bahasa, seperti membaca gambar, mengenal abjad, bahkan membaca dan menulis awal. Melalui $H L E$, anak-anak juga menujukkan kemampuannya dalam berkomunikasi yang lebih baik, seperti berbicara dan mengemukakan pendapat. Setiap kegiatan yang direncanakan dari adanya program HLE tentu harus dapat dilakukan secara konsisten agar hasil yang didapatkan pun juga lebih maksimal dan tentunya sesuai dengan tujuan yang diinginkan. Semakin kreatif dan semakin variatif kegiatan yang diberikan orang tua dalam program HLE maka akan semakin memberikan manfaat yang lebih banyak lagi bagi perkembangan anak. Hasil wawancara dan observasi dapat dilihat dari tabel 5 dan dokumentasi pada gambar 6, 7, 8 dan 9.

Tabel 5. Hasil Wawancara Aspek No. 3

\begin{tabular}{|c|c|c|}
\hline Pertanyaan & Inisial & Jawaban \\
\hline \multirow{15}{*}{$\begin{array}{l}\text { Bentuk kegiatan } \\
\text { apa yang Ibu } \\
\text { lakukan dalam } \\
\text { menyediakan } \\
\text { lingkungan } \\
\text { literasi di } \\
\text { rumah? }\end{array}$} & RZ & Kegiatan dalam menyediakan lingkungan literasi di rumah yaitu dengan \\
\hline & & menyediakan media yang dapat mengembangkan kemampuan \\
\hline & & membaca dan menulis. Orang tua dapat mendongengakan buku cerita \\
\hline & & yang dibacakan kepada anak dan memperlihatkan huruf-huruf dan kata \\
\hline & & yang dibacakan, menyediakan media yang dapat digunakan anak dalam \\
\hline & & $\begin{array}{l}\text { membuat coretan-coretan sederhana, memberikan kegiatan dengan } \\
\text { bantuan media APE yang terdapat huruf-huruf didalamnya dan menulis } \\
\text { dengan mencontoh huruf-hurufnya sehingga anak lebih tertarik. }\end{array}$ \\
\hline & WN & $\begin{array}{l}\text { Kegiatan yang bisa dilakukan yaitu dengan kita memberikan contoh, kita } \\
\text { menyempatkan untuk membaca buku, selain itu juga bisa mengajak } \\
\text { anak untuk bersama-sama membeli buku-buku, bisa pula dengan } \\
\text { membacakan buku pada anak sebelum tidur. }\end{array}$ \\
\hline & $\mathrm{HY}$ & $\begin{array}{l}\text { Memberikan contoh kepada anak berupa kebiasaan orang tua akan } \\
\text { seringnya membaca dan mengajak anak untuk membaca dengan cara } \\
\text { yang menyenangkan. }\end{array}$ \\
\hline & NC & $\begin{array}{l}\text { Membacakan cerita minimal satu buku setiap hari untuk menambah } \\
\text { wawasan dan informasi bagi anak. }\end{array}$ \\
\hline & AN & Membacakan cerita sebelum tidur. \\
\hline & NS & $\begin{array}{l}\text { Kegiatan membacakan cerita sebelum tidur, membiasakan anak untuk } \\
\text { menyukai buku. }\end{array}$ \\
\hline & VV & $\begin{array}{l}\text { Membacakan buku untuk anak, membuat buku sederhana bersama } \\
\text { anak. }\end{array}$ \\
\hline & TK & $\begin{array}{l}\text { Membacakan cerita, membaca buku bersama, menggambar dan } \\
\text { menceritakan kembali. }\end{array}$ \\
\hline & IN & $\begin{array}{l}\text { Menyediakan buku atau perpustakaan mini untuk anak dan melakukan } \\
\text { pembiasaan perilaku membaca setiap harinya. }\end{array}$ \\
\hline & WL & $\begin{array}{l}\text { Kegiatan yang bisa dilakukan di rumah dengan cara menyediakan media } \\
\text { yang dapat mengembangkan kemampuan literasi anak. Misal ketika } \\
\text { orang tua ingin mengajarkan pengenalan huruf, orang tua bisa } \\
\text { melakukannya dengan cara menggunakan media pembelajaran flash } \\
\text { card, memutarkan video pembelajaran interaktif, melakukan permainan } \\
\text { dengan berbantuan APE sehingga anak akan lebih tertarik dan tidak } \\
\text { merasa bosan. }\end{array}$ \\
\hline
\end{tabular}




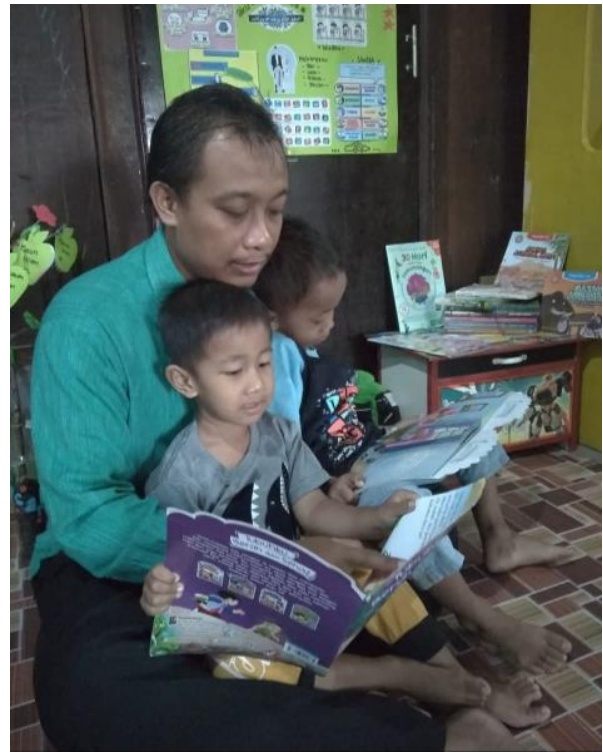

Gambar 6. Hasil observasi di rumah Ibu WN (Ayah FR sedang membacakan kisah Nabi pada anaknya).

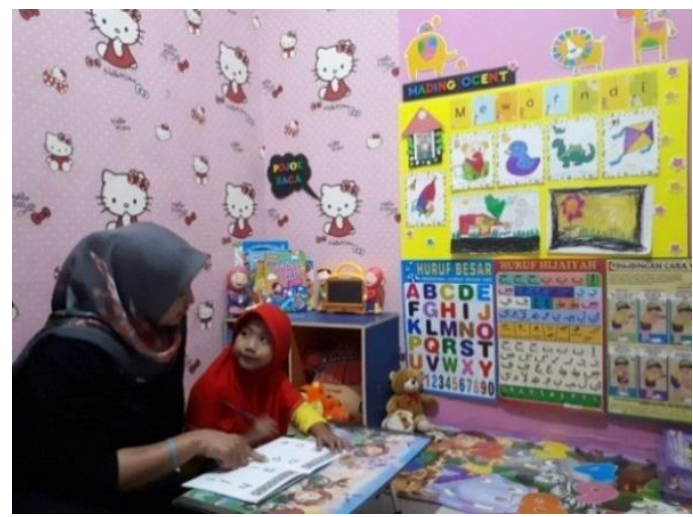

Gambar 8. Hasil observasi di rumah Ibu RZ

(Ibu RZ sedang mengenalkan macam-macam huruf dalam alfabet pada anaknya).

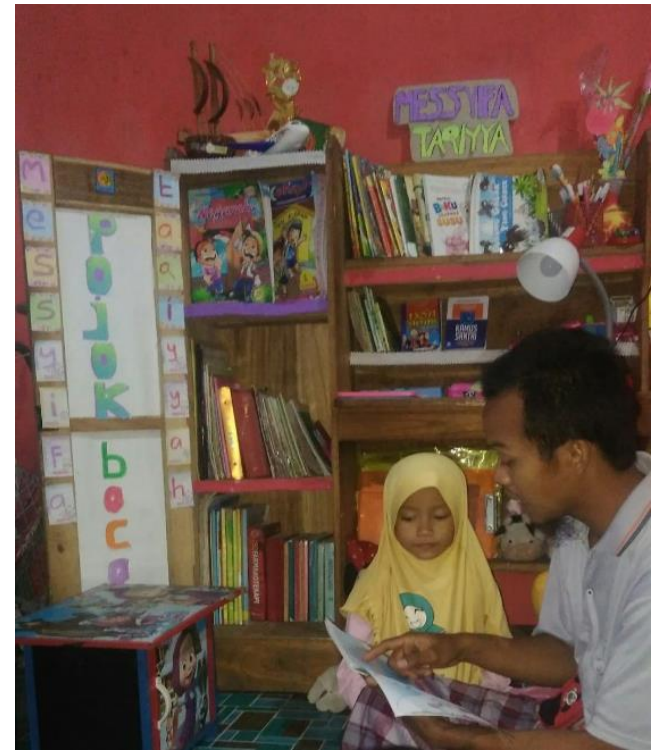

Gambar 7. Hasil observasi di rumah Ibu AN

(Ayah FT sedang membacakan cerita bergambar pada anaknya).

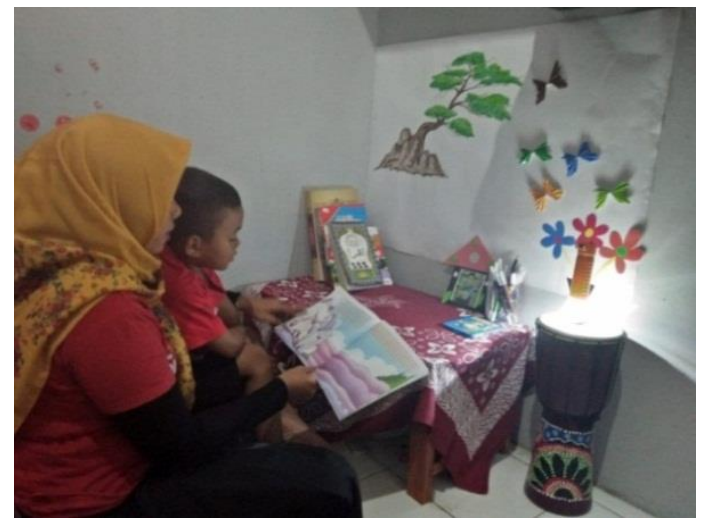

Gambar 9. Hasil observasi di rumah Ibu WL (Ibu WL sedang membacakan dongeng untuk anaknya).

Faktor yang mendukung orang tua dalam menyediakan Home Literacy Environment (HLE) Berdasarkan hasil wawancara dan observasi yang telah dilakukan, dapat disimpulkan bahwa faktor yang mendukung orang tua dalam menyediakan Home Literacy Environment (HLE) yaitu pembiasaan dalam keluarga, ketersediaan waktu orang tua, dan kelengkapan fasilitas literasi yang disediakan di rumah. Kegiatan HLE akan berjalan dengan maksimal apabila terjadi kerjasama yang baik antara kedua orang tua yaitu ibu dan ayah karena dalam hal ini mereka yang akan mengatur setiap kegiatan yang ada didalamnya. Tidak hanya ibu, peran ayah dalam mendidik anak juga sangat dibutuhkan. Dengan adanya $H L E$, hubungan antara ayah dengan anak juga akan menjadi lebih baik karena akan ada banyak kesempatan bagi ayah untuk bersama dengan anak sehingga akan terjadi lebih banyak interaksi dan komunikasi di antara mereka, baik melalui kegiatan literasi seperti dengan membacakan buku, cerita, dongeng, maupun belajar membaca dan menulis awal. Hasil wawancara dapat dilihat dari tabel 6. 
Tabel 6. Hasil Wawancara Aspek No. 4

\begin{tabular}{|c|c|c|}
\hline Pertanyaan & Inisial & Jawaban \\
\hline \multirow{10}{*}{$\begin{array}{l}\text { Menurut Ibu, faktor } \\
\text { apa yang dapat } \\
\text { mendukung Ibu dalam } \\
\text { menyediakan } \\
\text { lingkungan literasi di } \\
\text { rumah? }\end{array}$} & RZ & $\begin{array}{l}\text { Faktor kebiasaan orang tua untuk mengajak anak membaca bersama, } \\
\text { ketersediaan alat dan bahan untuk berliterasi di rumah seperti buku } \\
\text { dan APE. }\end{array}$ \\
\hline & $\mathrm{WN}$ & $\begin{array}{l}\text { Akses yang mudah untuk membeli buku dan waktu yang cukup } \\
\text { untuk berinteraksi setiap hari, dengan begitu akan dengan mudah } \\
\text { memberi pemahaman perlahan-lahan tentang literasi dan pentingnya } \\
\text { lingkungan literasi. }\end{array}$ \\
\hline & HY & Faktor pembiasaan. \\
\hline & NC & $\begin{array}{l}\text { Faktor minat membaca yang tinggi dan waktu yang mendukung } \\
\text { untuk melakukan program literasi di rumah. }\end{array}$ \\
\hline & AN & Faktor ketersediaannya sarana prasarana literasi. \\
\hline & NS & Waktu luang. \\
\hline & VV & $\begin{array}{l}\text { Waktu luang dimana ayah bunda memberikan kesempatan untuk } \\
\text { menikmati kegiatan anak. }\end{array}$ \\
\hline & TK & $\begin{array}{l}\text { Faktor kelengkapan peralatan belajar anak. Dengan lengkapnya } \\
\text { peralatan pendukung belajar, anak akan lebih mudah dalam belajar } \\
\text { dan menerima informasi baru. }\end{array}$ \\
\hline & IN & $\begin{array}{l}\text { Buku atau perpustakaan mini untuk anak dan pembiasaan perilaku } \\
\text { membaca setiap harinya. }\end{array}$ \\
\hline & WL & $\begin{array}{l}\text { Faktor yang mendukung terbentuknya lingkungan literasi di rumah } \\
\text { adalah kesadaran orang tua akan pentingnya perkembangan literasi } \\
\text { untuk anak, tersedianya fasilitas, dan pembiasaan. }\end{array}$ \\
\hline
\end{tabular}

Kendala yang dihadapi orang tua dalam menyediakan Home Literacy Environment (HLE)

Berdasarkan hasil wawancara dan observasi yang telah dilakukan, dapat disimpulkan bahwa kendala yang dihadapi orang tua dalam menyediakan Home Literacy Environment (HLE) yaitu minat anak, ketersediaan waktu orang tua, dan kelengkapan fasilitas literasi yang disediakan di rumah. Orang tua merupakan kunci utama dalam proses implementasi kegiatan $H L E$, sedangkan anak merupakan sasaran utama untuk dapat terlaksananya kegiatan tersebut. Dalam pelaksanaannya pun tentunya orang tua harus memperhatikan tahapan perkembangan belajar anak mengingat anak usia dini merupakan anak yang masih membutuhkan arahan dari orang yang lebih dewasa sehingga orang tua dituntut untuk dapat menjadi lebih kreatif khususnya dalam hal menarik minat belajar dan berliterasi anak usia dini. Orang tua juga harus dapat memberikan apresiasi terhadap setiap perkembangan yang ditunjukkan oleh anak. Apresiasi yang diberikan pun tidak melulu harus dalam bentuk hadiah, tetapi dapat berupa sebuah motivasi yang dapat membangun semangat anak untuk terus belajar dan mencintai dunia literasi khususnya ketika berada di rumah. Hasil wawancara dapat dilihat dari tabel 7.

Lingkungan literasi di rumah atau Home Literacy Environment (HLE) merupakan lingkungan yang menyediakan berbagai macam fasilitas yang dapat menunjang perkembangan literasi anak, baik itu berupa ruang baca, buku atau bahan bacaan maupun Alat Permainan Edukatif (APE) literasi. Lingkungan literasi di rumah merupakan penggambaran interaksi, sumber daya, dan sikap yang berkaitan dengan keaksaraan yang dijalani anak-anak ketika berada di rumah (Hamilton et al., 2016). Lingkungan keaksaraan di rumah mencakup apa yang dilakukan orang tua sebagai panutan (dampak pasif / implisit) dan kegiatan keaksaraan yang mereka lakukan dengan anak-anak mereka (dampak aktif / eksplisit) (Hofslundsengen et al., 2019). Dengan lingkungan ini, orang tua dapat membangun hubungan yang positif dan mengarahkan aktivitas anak agar lebih bermanfaat sehingga dapat mendukung anak dalam mencapai tugas-tugas perkembangan, khususnya perkembangan bahasa. 
Tabel 7. Hasil Wawancara Aspek No. 5

\begin{tabular}{|c|c|c|}
\hline Pertanyaan & Inisial & Jawaban \\
\hline $\begin{array}{l}\text { Kendala apa yang Ibu } \\
\text { hadapi dalam } \\
\text { menyediakan } \\
\text { lingkungan literasi di } \\
\text { rumah? }\end{array}$ & $\begin{array}{l}\text { AN } \\
\text { NS } \\
\text { VV } \\
\text { TK }\end{array}$ & $\begin{array}{l}\text { Kendala orang tua dalam menyediakan literasi di rumah yaitu } \\
\text { kurangnya ketersediaan waktu yang dimiliki orang tua dan } \\
\text { kurangnya sarana prasarana membaca yang mendukung literasi } \\
\text { anak (buku atau bahan bacaan yang masih sedikit). } \\
\text { Kendala yang dihadapi yaitu ketertarikan anak terhadap buku } \\
\text { yang dikalahkan oleh gadget. } \\
\text { Kurangnya fokus anak ketika dibacakan buku. } \\
\text { Kendala untuk meningkatkan minat membaca anak agar } \\
\text { mendapatkan informasi dari setiap buku. } \\
\text { Anak mudah bosan. } \\
\text { Kendalanya tempat dan buku. } \\
\text { Waktu, berbagai macam buku yang masih mahal. } \\
\text { Kurang lengkapnya atau kurang tersedianya peralatan belajar } \\
\text { anak. } \\
\text { Faktor dari dalam diri anak, karena anak memiliki tingkat } \\
\text { kebosanan masing-masing. Terkadang hari ini anak mau } \\
\text { melakukan membaca atau membuka buku, tapi di hari lain anak } \\
\text { hanya bermain. } \\
\text { Kendala yang dihadapi orang tua seperti kurangnya dukungan } \\
\text { dari keluarga (kakek nenek), sarana dan prasarana } \\
\text { pengembangan literasi yang belum memadai, dan waktu. }\end{array}$ \\
\hline
\end{tabular}

Lingkungan literasi di rumah sangat penting bagi anak usia dini karena dapat mempengaruhi perkembangan bahasa anak dimana perkembangan tersebut juga akan berpengaruh terhadap kehidupan dan masa depan anak nantinya. HLE yang positif tidak hanya membekali anak dengan prasyarat yang lebih baik di taman kanakkanak, tetapi juga secara langsung mendukung pengembangan kompetensi mereka lebih lanjut hingga awal sekolah dasar (Niklas \& Schneider, 2013). Sebelum menyediakan lingkungan literasi di rumah, orang tua perlu memperhatikan kebutuhan-kebutuhan apa saja yang diperlukan untuk menunjang setiap program-program literasi yang ada didalamnya (seperti fasilitas literasi dan ketersediaan waktu orang tua). Lingkungan yang nyaman dapat memberikan fokus belajar dan menjadikan anak bekerja dengan baik karena ini merupakan salah satu dasar belajar anak (Kumalasari \& Sugito, 2020). Lebih lanjut dikemukakan bahwa anak-anak dengan karakteristik lingkungan yang berkualitas tinggi selama tiga tahun pertama mereka harus lebih baik daripada anak-anak yang memiliki pengalaman awal. Orang tua adalah kunci dasar dalam penyediaan literasi di rumah. Sebagai pendidik pertama anak mereka, orang tua yang akan menentukan keterampilan literasi apa yang akan diajarkan kepada anak mereka. Lingkungan keaksaraan rumah yang disediakan orang tua untuk anak-anak mereka kemungkinan besar merupakan kontributor terpenting bagi pembelajaran keaksaraan anakanak prasekolah (Hofslundsengen et al., 2019).

Pengetahuan dan kesadaran orang tua akan pentingnya literasi sejak dini diidentifikasi sebagai aspek penting yang harus dimiliki orang tua. Sudah semestinya orang tua memahami dampak positif dari literasi sejak dini sehingga setiap program literasi yang dijalankan orang tua dapat berjalan secara terarah dan konsisten. Keterlibatan orang tua dalam pendidikan anak dapat memberikan pengaruh besar pada prestasi belajar anak. Keterlibatan orang tua dalam literasi anak adalah variabel terkuat di antara semua variabel latar belakang lainnya seperti kelas sosial, ukuran keluarga dan tingkat pendidikan orang tua (Fatonah, 2020). Orang tua berperan lebih penting dalam prestasi akademik siswa daripada sekolah dan masyarakat (Li \& Qiu, 2018). 
Literasi anak dapat terbangun apabila orang tua menjadikan kegiatan berliterasi sebagai suatu pembiasaan dalam keluarga. Kebiasaan literasi yang diberikan oleh orang tua dapat memprediksi kemampuan membaca anak dan kualitas kompetensi literasi anak di kemudian hari (Niklas et al., 2016). Pembiasaan literasi di rumah dapat terbentuk apabila orang tua mampu mengimplementasikan setiap program-program kegiatan yang ada didalamnya dengan baik dan teratur. Pembacaan buku bersama, kemungkinan merupakan aspek yang paling banyak dipelajari dari keaksaraan di rumah. Penelitian menunjukkan bahwa frekuensi membaca buku yang dipimpin oleh orang tua berhubungan positif dengan keterampilan bahasa lisan anak-anak (Guo et al., 2021). Belajar membaca di tahun-tahun awal pendidikan memberikan landasan bagi pengembangan literasi dan kesuksesan akademis di kemudian hari (Hamilton et al., 2016). Efek membaca bersama ditemukan penting untuk keterampilan bahasa lisan (kosakata dan pemahaman mendengarkan) pada semua titik waktu di mana keterampilan tersebut diukur (Silinskas et al., 2020). Melalui pembiasaan literasi sejak dini ini maka dunia literasi anak secara tidak langsung akan mulai terbangun secara perlahan.

Terciptanya Home Literacy Environment (HLE) yang positif tentu tidak terlepas dari beberapa faktor yang mendukung dan menghambat dalam penyediaannya. Faktor tersebut bisa datang dari orang tua, anak, maupun fasilitas literasi di rumah. Pertama, orang tua harus terlibat aktif dalam kegiatan literasi anak agar mereka dapat mendukung dan memotivasi anak dalam kegiatan berliterasi mengingat anak usia dini merupakan anak yang masih memerlukan pendampingan dari orang dewasa sehingga orang tua harus tetap terlibat dalam setiap aktivitas yang dilakukan oleh anak. Keterlibatan orang tua penting untuk mendukung pembelajaran anak (Fatonah, 2020). Lebih lanjut dikemukakan bahwa keterlibatan orang tua berhubungan langsung dengan prestasi dan motivasi. Oleh karena itu, semakin banyak keterlibatan orang tua dalam pendampingan belajar anak maka akan semakin baik prestasi dan motivasi anak dalam berliterasi.

Keterlibatan orang tua tentunya juga berkaitan erat dengan ketersedian waktu yang dimilikinya. Pola kerja orang tua juga dapat membatasi waktu untuk terlibat dalam kegiatan membaca bersama anak-anak mereka (Mascarenhas et al., 2017). Semakin banyak waktu yang disediakan maka semakin banyak pula keterlibatan yang akan mereka berikan. Beberapa orang tua berusaha untuk memberikan waktu yang cukup bagi anaknya, akan tetapi konsistensi ketersediaan waktu untuk memberikan kegiatan literasi di rumah juga sangat diperlukan (Dimosthenous et al., 2020). Selain itu, tingkat pengetahuan yang dimiliki orang tua tentu juga berhubungan. Orang tua yang memiliki tingkat pendidikan tinggi dan memiliki pemahaman yang baik mengenai dampak dari literasi di rumah bagi anak cenderung lebih berkreativitas dalam menciptakan lingkungan literasi di rumah. Orang tua dengan tingkat kualifikasi pendidikan tinggi cenderung menciptakan lingkungan yang secara intelektual merangsang anak mereka dalam pendidikan dan kehidupan sosial (Mekonnen, 2017). Meskipun demikian, tidak menutup kemungkinan pula bahwa orang tua yang memiliki tingkat kualifikasi pendidikan rendah dan pemahaman yang cukup tidak mampu menyediakan lingkungan literasi di rumah dengan baik mengingat setiap orang tua pasti memiliki keinginan yang besar untuk memberikan pelayanan yang terbaik untuk anaknya. Pengalaman dan minat orang tua dalam kegiatan membaca dan menulis biasanya mencerminkan pendidikan orang tua (Hofslundsengen et al., 2019).

Kedua, kegiatan literasi yang diberikan oleh orang tua tidak akan terimplementasi dengan baik apabila anak sebagai sasaran literasi di rumah tidak ikut terlibat aktif dalam setiap program literasi yang diberikan. Keterlibatan anak usia dini dalam membaca buku terkait dengan kesadaran fonemik, konstruksi naratif, keterampilan kosakata, konsep pengetahuan, dan sikap positif terhadap literasi (Tamis-LeMonda et al., 2019). Anak usia dini merupakan anak yang memiliki daya konsentrasi yang lemah. Lingkungan literasi di rumah harus disediakan dengan senyaman mungkin sehingga anak dapat memiliki fokus belajar yang baik. Orang tua juga dituntut untuk lebih kreatif mengingat anak mudah bosan sehingga 
orang tua perlu mengembangkan kreativitasnya agar anak tetap memiliki minat yang tinggi dalam berliterasi.

Ketiga, adanya fasilitas literasi (seperti ruang baca, buku atau bahan bacaan, dan APE literasi) yang memadai tentu akan mendukung setiap program yang terdapat dalam lingkungan literasi di rumah. Fasilitas belajar yang memadai dapat mendukung peningkatan motivasi belajar anak (Rozi, 2020). Oleh karena itu, semakin bagus dan semakin lengkap fasilitas literasi yang disediakan maka anak akan semakin termotivasi dalam berliterasi. Akan tetapi, apabila fasilitas literasi ini hanya disediakan dengan apa adanya dan ala kadarnya saja tentu anak tidak akan memiliki motivasi untuk berliterasi dan tentunya akan merasa cepat bosan sehingga pada akhirnya mereka akan lebih memilih lingkungan bermain lainnya yang lebih menarik minatnya.

\section{SIMPULAN}

Peran orang tua dalam menyediakan HLE pada anak usia dini adalah sebagai sumber literasi (guru atau pendamping literasi bagi anak), fasilitator literasi (menyediakan ruang baca, buku atau bahan bacaan, dan APE literasi untuk anak), dan sebagai pengatur terlaksananya program literasi. Sedangkan, peran anak adalah sebagai sasaran utama orang tua dalam menerapkan HLE. HLE memberikan manfaat yang lebih banyak bagi perkembangan bahasa anak ketika orang tua dan anak dapat saling berkolaborasi secara aktif dalam setiap program kegiatannya. Adanya HLE juga membantu orang tua dalam memaksimalkan perannya dalam mendidik dan menstlimulasi perkembangan anak khususnya dalam mempersiapkan anak untuk memasuki jenjang pendidikan selanjutnya.

\section{UCAPAN TERIMA KASIH}

Puji syukur penulis panjatkan kehadirat Allah SWT yang telah memberikan kemudahan dalam proses penyusunan artikel ini. Penulis juga mengucapkan terima kasih kepada Dr. Drs. Sugito., MA sebagai pembimbing dan semua pihak yang telah terlibat dalam penelitian ini. Semoga penelitian ini dapat memberikan manfaat bagi institusi dan masyarakat luas.

\section{DAFTAR PUSTAKA}

Anderson, J., Anderson, A., \& Sadiq, A. (2017). Family literacy programmes and young children's language and literacy development: paying attention to families' home language. Early Child Development and Care, 187(3-4), 644-654. https://doi.org/10.1080/03004430.2016.1211119

Buvaneswari, B., \& Padakannaya, P. (2017). Development of a home literacy environment questionnaire for Tamil-speaking kindergarten children. Language Testing in Asia, 7(1). https:// doi.org/10.1186/s40468-017-0047-y

Dimosthenous, A., Kyriakides, L., \& Panayiotou, A. (2020). Short- and long-term effects of the home learning environment and teachers on student achievement in mathematics: a longitudinal study. School Effectiveness and School Improvement, 31(1), 50-79. https://doi.org/10.1080/09243453.2019.1642212

Fatonah, N. (2020). Parental Involvement in Early Childhood Literacy Development. 454(Ecep 2019), 193-198. https://doi.org/10.2991/assehr.k.200808.038

Flick, U. (2014). Mapping the Field. The SAGE Handbook of Qualitative Data Analysis. SAGE Publications Ltd. In The SAGE Handbook of Qualitative Data Analysis. https://doi.org/10.4135/9781446282243

Guo, Y., Puranik, C., Kelcey, B., Sun, J., Dinnesen, M. S., \& Breit-Smith, A. (2021). The Role of Home Literacy Practices in Kindergarten Children's Early Writing Development: A 
One-Year Longitudinal Study. Early Education and Development, 32(2), 209-227. https:// doi.org/10.1080/10409289.2020.1746618

Hamilton, L. G., Hayiou-Thomas, M. E., Hulme, C., \& Snowling, M. J. (2016). The Home Literacy Environment as a Predictor of the Early Literacy Development of Children at Family-Risk of Dyslexia. Scientific Studies of Reading, 20(5), 401-419. https:// doi.org/10.1080/10888438.2016.1213266

Hofslundsengen, H., Gustafsson, J. E., \& Hagtvet, B. E. (2019). Contributions of the Home Literacy Environment and Underlying Language Skills to Preschool Invented Writing. Scandinavian Journal of Educational Research, 63(5), 653-669. https:// doi.org/10.1080/00313831.2017.1420686

Kumalasari, P. I., \& Sugito, S. (2020). The Role of Student's Parent in Shaping Home Learning Environment (HLE) for Early Childhood. Jurnal Obsesi : Jurnal Pendidikan Anak Usia Dini, 5(2), 1521-1535. https://doi.org/10.31004/obsesi.v5i2.881

Li, Z., \& Qiu, Z. (2018). How does family background affect children's educational achievement? Evidence from Contemporary China. Journal of Chinese Sociology, 5(1). https://doi.org/10.1186/s40711-018-0083-8

Madyawati. (2016). Strategi Pengembangan Bahasa pada Anak. Kencana.

Mascarenhas, S. S., Moorakonda, R., Agarwal, P., Lim, S. B., Sensaki, S., Chong, Y. S., Allen, J. C., \& Daniel, L. M. (2017). Characteristics and influence of home literacy environment in early childhood-centered literacy orientation. Proceedings of Singapore Healthcare, 26(2), 81-97. https:/ / doi.org/10.1177/2010105816674738

Mekonnen, M. A. (2017). Effects of Family Educational Background, Dwelling and Parenting Style on Students' Academic Achievement: The Case of Secondary Schools in Bahir Dar. Educational Research and Reviews, 12(18), 939-949. https:/ / doi.org/10.5897/ERR2017.3276

Miles, M. B., \& Huberman, A. M. (1994). Qualitative Data Analysis: An Expand Sourcebook (2nd ed.). Sage Publications.

Miles, M. B., Huberman, A. M., \& Saldana, J. (2014). Qualitative Data Analysis: An Expand Sourcebook (3rd ed.). Sage Publications.

Miller, J. M., \& McKenna, M. C. (2016). World Literacy How Countries Rank and Why It Matters (1st ed.). Routledge. https:// doi.org/10.4324/9781315693934

Niklas, F., Cohrssen, C., \& Tayler, C. (2016). Parents supporting learning: a non-intensive intervention supporting literacy and numeracy in the home learning environment. International Journal of Early Years Education, 24(2), 121-142. https:// doi.org/10.1080/09669760.2016.1155147

Niklas, F., \& Schneider, W. (2013). Home Literacy Environment and the beginning of reading and spelling. Contemporary Educational Psychology, 38(1), 40-50. https:// doi.org/10.1016/j.cedpsych.2012.10.001

Perpustakaan Nasional. (2020). Peraturan Perpustakaan Nasional Republik Indonesia Nomor 7 Tahun 2020 Tentang Rencana Strategis Perpustakaan Nasional Tahun 2020-2024. Agustus 2020.

Puglisi, M. L., Hulme, C., Hamilton, L. G., \& Snowling, M. J. (2017). The Home Literacy Environment Is a Correlate, but Perhaps Not a Cause, of Variations in Children's Language and Literacy Development. Scientific Studies of Reading, 21(6), 498-514. https:// doi.org/10.1080/10888438.2017.1346660

Rose, E., Lehrl, S., Ebert, S., \& Weinert, S. (2018). Long-Term Relations Between Children's Language, the Home Literacy Environment, and Socioemotional Development From Ages 3 to 8 . Early Education and Development, 29(3), 342-356. https://doi.org/10.1080/10409289.2017.1409096

Rozi, M. F. (2020). Pengaruh Fasilitas Belajar Terhadap Motivasi Belajar Taruna Poltekip Tingkat Ii Prodi Manajemen Pemasyarakatan. 3, 97-106.

1380 | Jurnal Obsesi : Jurnal Pendidikan Anak Usia Dini, 6(3), 2022 
Silinskas, G., Torppa, M., Lerkkanen, M. K., \& Nurmi, J. E. (2020). The home literacy model in a highly transparent orthography. School Effectiveness and School Improvement, 31(1), 80-101. https://doi.org/10.1080/09243453.2019.1642213

Tamis-LeMonda, C. S., Luo, R., McFadden, K. E., Bandel, E. T., \& Vallotton, C. (2019). Early home learning environment predicts children's 5th grade academic skills. Applied $\begin{array}{lll}\text { Developmental } \quad \text { Science, } & \text { 23(2), }\end{array}$ https:// doi.org/10.1080/10888691.2017.1345634

Weigel, D. J., Martin, S. S., \& Lowman, J. L. (2017). Assessing the early literacy skills of toddlers: the development of four foundational measurest. Early Child Development and Care, 187(3-4), 744-755. https:// doi.org/10.1080/03004430.2016.1236089

Yusuf. (2017). Metode Penelitian Kuantitatif, Kulitatif \& Penelitian Gabungan. Kencana.

Zhang, S. Z., Inoue, T., Shu, H., \& Georgiou, G. K. (2020). How does home literacy environment influence reading comprehension in Chinese? Evidence from a 3-year longitudinal study. Reading and Writing, 33(7), 1745-1767. https://doi.org/10.1007/s11145-019$\underline{09991-2}$ 